\title{
MOTIF DALAM MEMILIH PANGAN DAN HUBUNGANNYA DENGAN KETAHANAN PANGAN PADA KOMUNITAS NELAYAN DI SUMATERA BARAT
}

\section{Motives in Food Choices and It's Influences to Food Security among Fishers Communities of West Sumatera}

\author{
*Sriwulan Ferindian Falatehan ${ }^{1}$ dan Pariyasi \\ ${ }^{1}$ Departemen Sains Komunikasi dan Pengembangan Masyarakat, \\ Fakultas Ekologi Manusia, IPB University \\ Jl. Raya Dramaga Kampus, IPB Dramaga Bogor, 16680 Jawa Barat, Indonesia \\ 2Universitas Negeri Padang \\ Jalan Prof. Dr. Hamka Air Tawar Padang, Sumatera Barat \\ Diterima tanggal: 10 Agustus 2019 Diterima setelah perbaikan: 22 Maret 2021 \\ Disetujui terbit: 25 Juni 2021
}

\begin{abstract}
ABSTRAK
Ketahanan pangan adalah kondisi terpenuhinya kebutuhan pangan dilihat dari jumlah, kualitas, dan gizi yang seimbang. Dalam tindakan pemenuhan kebutuhan pangan individu dalam suatu konteks tertentu, terdapat motif yang mempengaruhinya, seperti kesehatan, sosial, ekonomi, dan budaya. Selain itu ada kepemilikan modal individu dapat mempengaruhi tindakan memilih dan mengkonsumsi pangan serta kondisi pemenuhan ketahanan pangannya. Mengacu pada hal tersebut, tujuan penelitian ini adalah untuk: 1) menganalisis perbedaan perilaku memilih pangan berdasarkan empat motif, yaitu sosio-ekonomi-budaya-kesehatan menurut kepemilikan modal budaya, ekonomi, dan sosial; dan 2) menguji hubungan antara perilaku memilih pangan dengan ketahanan pangan. Penelitian ini menggunakan pendekatan kuantitatif dengan survey pada 30 orang nelayan di Kabupaten Pariaman, Provinsi Sumatera Barat dalam konteks melaut mulai mendekati masa paceklik dalam penangkapan ikan. Responden tersebar pada lapisan sosial atas (Induak Samang) dan bawah (Anak Buah Kapal) yang didukung dengan data kualitatif dari wawancara mendalam. Metode analisis yang digunakan adalah Uji beda proporsi Mann-Whitney U Test dan korelasi Rank-Spearman sementara itu hasil wawancara dianalisis secara deskriptif. Hasil penelitian menunjukkan terdapat perbedaan perilaku memilih pangan dari empat motif berdasarkan modal budaya dan ekonomi; serta adanya hubungan perilaku memilih pangan dengan ketahanan pangan sebesar 0,33 $(\alpha<0,05)$. Model tindakan memilih pangan berdasarkan empat motif tersebut dapat digunakan sebagai salah satu indikator ketahanan pangan baik oleh Badan Ketahanan Pangan, Kementerian Pertanian, Kementerian Perikanan dan Kelautan maupun pemerintah dan kelembagaan yang berkaitan langsung dengan pemenuhan pangan dan kesehatan untuk mengurangi jumlah penduduk yang rawan pangan baik melalui proram Desa Mandiri Pangan maupun program pemberdayaan lainnya.
\end{abstract}

Kata Kunci: ketahanan pangan; komunitas nelayan; modal budaya; modal ekonomi; perilaku memilih pangan

\begin{abstract}
Food security fulfills food needs regarding quantity, quality, and balanced nutrition. Several motives influence food choice behavior in specific contexts, such as health, social, cultural, and economic. In addition, there is capital in individual that determine the tendency for actors in their food choice behavior and food security. Furthermore, the objectives of this study were: 1) analyze food choice behavior from four motives, such as socio-economic-cultures-health based on culture, economic, and social capital; and 2) assess the correlation between food choice behavior and food security. This study used survey techniques from 30 fishers in Pariaman District, West Sumatera Province, regarding the instability of their fishing behavior and shortage season. Respondents comprised of upper and lower social classes supported by qualitative data from depth-interviewed. Method analysis used a Mann-Whitney $U$ to assess the proportion differences and Rank Spearman, whereas the interview scripts were analyzed with descriptive. Data show the differences in food choices behavior in four-motives based on cultural
\end{abstract}


and economic capital. In addition, there is a positive correlation between food choice behavior and food security at $0.33(\alpha<0,05)$. Many agencies, namely Food Security Board, the Ministry of Agriculture, the Ministry of Marine Affairs and Fisheries, and other institutions which concern about food security might provide the four-motives model in food choices behavior as an optional indicator of food security when implementing the Food Sufficiency Village program or the other empowerment programs.

\section{Keywords: food security; fishers community; cultural capital; economic capital; food choice} behavior

\section{PENDAHULUAN}

Pembangunan berkelanjutan tanpa kelaparan, menjadi salah satu target Sustainable Development Goals (SDGs) diakomodir hampir semua negara di dunia. Hal ini dilatarbelakangi adanya masalah terkait pola makan yang kurang baik (Vilaro, Barnett, Mathews, Pomeranz, \& Curbow, 2016), seperti kurang nutrisi (malnutrition), kurang berat badan (stunting), nutrisi berlebih (overnutrition) dan obesitas (Rachmi, Hunter, $\mathrm{Li}$, \& Baur, 2018). Di Indonesia, ketidakcukupan energi kronik merupakan penyebab stunting dan menjadi salah satu perhatian dalam pemenuhan pangan pada skala nasional (Atmarita, 2018) di tengah peningkatan jumlah penduduk (Syaukat, 2012). Undang-Undang Republik Indonesia Nomor 18 Tahun 2012 tentang Pangan memuat definisi Ketahanan Pangan sebagai sebuah kondisi terpenuhinya pangan bagi negara sampai dengan perseorangan dengan tersedianya pangan, baik jumlah maupun mutunya, aman, beragam, bergizi, merata, dan terjangkau. Ketahanan pangan juga berarti situasi tercukupinya kebutuhan pangan di tingkat rumahtangga (Damayanti, 2007). Dimensi ketahanan pangan meliputi ketersediaan pangan, akses pangan, dan pemanfaatan pangan (Badan Ketahanan Pangan, 2018b, 2018a).

Beragam upaya untuk mewujudkan ketahanan pangan pada berbagai komunitas tampak dipengaruhi oleh banyak faktor, salah satunya adalah motif dalam memilih pangan. Beberapa pendekatan yang sudah mengkaji perilaku pemilihan pangan ini seperti sosiologi, psikologi, antropologi maupun ilmu pangan itu sendiri. Teori Strukturasi dari Giddens yang digunakan oleh Prasodjo (2017) melihat peran struktur dan agensi dianggap memiliki hubungan interplay dalam membentuk praktik pilihan pangan pengelola pangan anak balita di komunitas pertanian sawah irigasi dataran rendah dan komunitas pertanian tadah hujan dataran tinggi; sementara konsep modal budaya dari Bourdieu (1984) juga nampak dalam preferensi pangan dari kelas sosial yang berbeda (Clercq et al., 2016). Motif yang mempengaruhi perilaku pemilihan pangan (food choice) dari psikologi dan ilmu pangan, yaitu kesehatan, selera, kenyamanan, daya tarik sensorik, bahan alami, harga, pengawasan berat badan, familiarity, etika, rasa, keyakinan, sejarah keluarga, dan rutinitas (Markovina et al., 2015; Steptoe, Pollard, \& Wardle, 1995; Vilaro et al., 2016). Sementara faktor lain yang mempengaruhi perilaku pangan yaitu sosial, faktor personal, faktor psikologi, faktor kultural, dan faktor lain (Agus \& Budiyanto, 2012); serta kepercayaan, status sosial dalam masyarakat, dan kebiasaan yang terinternalisasi sejak kecil (Nurdin \& Kartini, 2017). Hal ini menunjukkan bahwa kebiasaan pangan dan kaitannya dengan ketahanan pangan menjadi penting untuk dikaji, termasuk di komunitas nelayan yang khas karakteristik sosial ekonominya.

Pilihan pangan yang di dalamnya terdapat pengaruh faktor psikologi, sosial, dan budaya, tidak hanya mempengaruhi kesehatan dan kesejahteraan di tingkat individu, namun juga sistem pangan dari produksi, proses hingga distribusi di tingkat regional, nasional, dan global (Roudsari et al., 2017; Sobal, Bisogni, Devine, \& Jastran, 2006). Pilihan pangan terkait dengan seleksi dan mengkonsumsi pangan dipengaruhi oleh tahapan kehidupan, pengaruh (sosial, sumberdaya, personal, idealisme, dan konteks), dan sistem personal (nilai rasa, biaya, kesehatan, dan kepastian) (Sobal et al., 2006). Motif pemilihan pangan, yaitu properti sensori, efek mengkonsumsi, dan pertimbangan idealis akan asal pangan, berperan penting pada penerimaan bahan pangan tertentu ke dalam tindakan konsumsi pangan individu (Rozin, 2006). Sementara itu penelitian sebelumnya mengenai motif pemilihan pangan ini sudah banyak dilakukan untuk menganalisis kebiasaan pangan dalam suatu komunitas dengan menggunakan Food Choice Questionnaire (FCQ). 
FCQ merupakan instrumen yang digunakan untuk mengidentifikasi sembilan motif pemilihan pangan (food choice), yaitu kesehatan, selera, kenyamanan, daya tarik sensorik, bahan alami, harga, pengawasan berat badan, familiar, dan etika (Steptoe et al., 1995). Didapati bahwa terdapat beberapa motif yang dianggap paling penting oleh responden, seperti familiarity, pertimbangan etika, dan pengawasan berat badan (Markovina et al., 2015); kandungan alami dalam pangan, kesehatan, dan harga (Puspadewi \& Briawan, 2014); serta kesehatan dan konteks sosial (Kahma, Niva, Helakorpi, \& Jallinoja, 2016). Hasil ini menunjukkan bahwa terdapat perbedaan motif yang dianggap paling penting pada individu dalam memilih pangannya.

Hal lain yang diidentifikasi adalah adanya pengaruh faktor individu dan sosial yang mempengaruhi perilaku pemilihan pangan, seperti ketetanggaan (Vilaro et al., 2016); dan pengaruh orang lain yaitu kerabat keluarga, dan tetangga (Agus \& Budiyanto, 2012). Oleh karena itu, menurut peneliti, penting untuk mengetahui faktor atau motif yang mempengaruhi individu dalam memilih pangannya. Peneliti menganggap adanya kesatuan dari empat faktor yaitu kesehatan, harga, pengaruh sosial, dan kebiasaan yang menjadi seperangkat motif yang memengaruhi perilaku pemilihan pangan, termasuk pada komunitas nelayan.

Hal ini perlu dilakukan karena peneliti menduga bahwa terdapat keberadaan seperangkat motif yang mendasari perilaku pemilihan pangan pada nelayan sebagai komunitas yang sering dianggap memiliki keterbatasan pendapatan, jaringan sosial, maupun tingkat pendidikan dalam strategi nafkah sebagai nelayan. Terlebih lagi pada masa paceklik yang membuat kegiatan melaut nelayan menjadi tidak menentu dan hasil tangkapan yang menurun. Pengeluaran rumah tangga nelayan mencapai $83 \%$ untuk pangan (Alpharesy, Anna \& Yustiati, 2012) sehingga dapat terjadi keterbatasan dari pendapatan dalam menyediakan makanan di rumahnya (Rachmi et al., 2018). Kajian Salim \& Darmawaty (2016) mengidentifikasi kategori ketahanan pangan pada rumahtangga nelayan buruh adalah rendah mencakup tidak tahan pangan (92,78\%) dan kurang tahan pangan (7,22\%). Tidak adanya rumahtangga nelayan buruh termasuk dalam kategori tahan pangan dapat terjadi karena akses yang sulit terhadap pangan, khususnya dari sisi akses ekonomi seperti pendapatan, kesempatan kerja, dan harga pangan (Salim \& Darmawaty, 2016).

Pengelompokkan sosial pada komunitas nelayan terdiri dari ponggawa (pemilik modal), juragan kapal, dan buruh atau pandega, yang membentuk pembagian kerja, pendapatan, pengeluaran, dan curahan kerja (Saleha, 2013). Peneliti melihat hal ini dipengaruhi perbedaan kepemilikan modal budaya, ekonomi, dan sosial di antara nelayan. Modal dilihat Bourdieu (1986) sebagai potensi untuk menghasilkan keuntungan yang dapat diakumulasi dengan bentuk turunannya yang melekat pada habitus aktor, membutuhkan waktu dan berdampak pada ketidaksamaan. Peneliti menduga ada pengaruh tiap modal ini pada bekerjanya empat motif pemilihan pangan dengan konsep modal dari Bourdieu (1986).

Modal budaya seperti latar belakang pendidikan diidentifikasi secara positif berhubungan dengan motif pemilihan pangan yang sesuai standar kesehatan (Kamphuis, Jansen, Mackenbach \& Lenthe, 2015). Hal ini menunjukkan bahwa modal budaya juga dapat dilihat pengaruhnya dalam perilaku pemilihan pangan pada nelayan. Sementara itu dari lapisan ekonomi terkait penguasaan moda produksi tangkapan ikan yang mempengaruhi pendapatan sebagai modal ekonomi juga nampak dapat mempengaruhi pola pemilihan pangan pada nelayan. Vilaro et al. (2016) menyatakan perempuan yang memiliki pendapatan di atas rata-rata memiliki keteraturan dari norma sosial dan regulasi diri dalam menjaga pola makan sehatnya dibandingkan dengan perempuan dari lapisan sosial ekonomi yang lebih rendah. Modal yang terakhir yaitu modal sosial dari kondisi kerja ini diduga menyebabkan kepercayaan, jaringan sosial dan aturan yang ada di komunitas dapat memengaruhi nelayan dalam memenuhi kebutuhan pangannya. Modal sosial berupa saling membantu dan percaya antar anggota dalam rumahtangga dapat berperan untuk mengatasi masalah pangan (Endarwati \& Wahyuni, 2014; Martianto, Alfiasari, \& Dharmawan, 2017). Tiga unsur dari modal sosial, yaitu jaringan sosial, norma sosial, dan kepercayaan (Putnam, 2000).

Dengan demikian maka penelitian mengenai seperangkat motif yang membentuk perilaku pemilihan pangan pada komunitas nelayan ini akan mengacu pada kerangka modal ekonomi budaya, dan sosial (Bourdieu, 1986). Tujuan penelitian ini adalah untuk: 1) menganalisis perilaku memilih pangan berdasarkan empat motif menurut 
kepemilikan modal; serta 2) Mengidentifikasi hubungan motif dalam perilaku memilih pangan dengan ketahanan pangan konteks masa peralihan mendekati masa paceklik.

\section{METODOLOGI}

\section{Lokasi dan Waktu Peneltian}

Penelitian dilakukan pada bulan April sampai November 2018 di Desa Marunggi dan Taluk, Kecamatan Pariaman Selatan, Kabupaten Pariaman, Provinsi Sumatera Barat, pada masa peralihan mendekati musim paceklik. Musim paceklik di wilayah ini biasanya terjadi pada musim Barat yaitu antara bulan DesemberJanuari. Dalam sebulan terakhir nelayan sulit memperoleh hasil tangkapan yang maksimal dan fluktuatif hasilnya seiring dengan sulitnya melaut karena gelombang sering tinggi. Nelayan kadang pulang dengan hasil tangkapan sedikit dan pernah tidak mendapatkan ikan sama sekali, namun tetap masih ada kondisi dimana nelayan memperoleh tangkapan ikan.

Desa-desa di kecamatan ini merupakan komunitas pesisir yang bergantung dengan kondisi alam yang sebagian mata pencaharian masyarakatnya sebagai nelayan penuh. Data kelompok pelaku utama perikanan (2016), Desa Taluk memiliki nelayan berjumlah 20 nelayan sementara itu Data Monografi Desa Marunggi tahun 2016 menyebutkan adanya 26 nelayan. Pemilihan responden di dua desa ini dilakukan dengan pertimbangan adanya interaksi sosial antara Anak Buah Kapal (ABK) sebagai lapisan bawah dan Induak Samang sebagai lapisan atas dalam aktivitas melaut sebagai strategi nafkah mereka.

\section{Jenis dan Metode Pengambilan Data}

Data yang digunakan dalam penelitian ini adalah data primer dan data sekunder. Data primer berasal dari teknik survei dengan kuesioner, wawancara kepada informan dan responden, serta observasi lapang. Teknik penentuan responden dilakukan secara purposive (sengaja) yang terdiri dari dua lapisan sosial nelayan, yaitu lapisan bawah (Anak Buah Kapal) dan kelas atas (Induak Samang) di tiap desa. Survey dilakukan secara accidental sampling pada 15 orang di tiap desa sehingga jumlah keseluruhan responden adalah 30 orang. Informan dalam penelitian ini melibatkan ketua kelompok nelayan serta sesepuh atau tetua yang dihormati oleh masyarakat, yang dapat menjadi mediator sekaligus pemersatu masyarakat dengan menerapkan nilai norma dan kebiasaan dari turun-temurun seperti kegiatan mendoa (berkumpul dan makan bersama) yang menjadi kegiatan rutin yang ada di komunitas. Sementara itu data sekunder diperoleh dari studi literatur dan informasi tertulis yang berkaitan dengan kebiasaan pangan di komunitas nelayan. Informasi tertulis dalam penelitian ini diperoleh dari kepala desa dan pusat kesehatan (puskesmas) setempat berupa dokumen tertulis seperti monografi desa dan data kesehatan.

Definisi operasional pemilihan pangan (food choice) dikelompokkan dari empat motif, yaitu Kesehatan, Harga, Pengaruh orang lain, dan Kebiasaan. Perilaku memilih pangan dinilai dengan variasi jawaban Ya dan Tidak meskipun pada awalnya pertanyaanmengenai tingkat kepentingan motif dalam Food Choice Questionnaire (FCQ) sebelumnya diukur dengan menggunakan 4 pilihan (Puspadewi \& Briawan, 2014), 5 pilihan (Kahma et al., 2016) atau 7 pilihan (Markovina et al., 2015; Steptoe et al., 1995) dari Sangat Tidak Penting hingga Sangat Penting. Dua motif yang berasal dari FCQ yaitu kesehatan dan harga. Meski begitu, item yang digunakan dalam penelitian ini didesain baru yang mengakomodir perilaku yang dianggap khas pada nelayan di Indonesia. Dengan demikian maka item pada aspek kesehatan tidak hanya seperti di FCQ yang ditanyakan tentang aspek nutrisinya secara detail, seperti kandungan protein, vitamin dan mineral, dan zat besi, dan manfaatnya untuk kulit/gigi/rambut, namun lebih pada keseimbangan gizi yang seharusnya dimiliki pada sayuran, beras, dan tidak hanya lauk, beras sehingga secara total jumlah pertanyaan adalah sebanyak 19 buah. Hal ini disebabkan karena konsumsi beras di Indonesia termasuk tinggi yang jumlahnya akan lebih banyak dibandingkan lauknya serta kurang mengkonsumsi makanan berserat. Sementara itu untuk aspek harga, tidak hanya murah yang dilihat tapi juga dilihat dalam banyak dan harganya.

Analisis penelitian ini berdasarkan kerangka modal, yaitu budaya, ekonomi, dan sosial pada ketahanan pangan. Modal budaya dioperasionalkan tingkat pendidikan tertinggi yang diselesaikan oleh responden, yaitu Rendah ketika menamatkan Sekolah Dasar (SD), Sekolah Menengah Pertama 
(SMP), dan Sekolah Menengah Atas (SMA); serta Tinggi ketika mengambil pendidikaan di tingkat Diploma dan Sarjana. Adapun modal ekonomi dilihat dari lapisan sosial ekonomi dengan indikator jenis kepemilikan moda produksi (kapal) dalam penangkapan ikan dan status yang melekat selama mereka melaut. Kepemilikkan moda produksi yaitu berupa jenis kapal, yaitu longtel (perahu tanpa motor), payang (perahu motor), dan bagan (kepala motor). Penamaan kapal tersebut adalah khas dari daerah Pariaman yang menunjukkan kapasitas tiap kapal dalam memuat orang dan jangkauan jejak kapal dari pantai. Kapal yang paling kecil yaitu kapal longtel dengan kapasitas muatan 2 orang, kapal payang (kapal sedang) dengan kapasitas muatan mencapai 12 orang, dan kapal bagan adalah kapal yang paling besar dengan kapasitas muatan mencapai 15 orang. Sementara itu, status responden terbagi dalam 2 kategori yaitu: Induak samang merupakan lapisan atas sebagai pemilik kapal dan ABK (anak buah kapal) merupakan lapisan bawah sebagai buruh. Oleh karena itu modal ekonomi akan termasuk lemah ketika moda produksi longtel, berstatus sebagai ABK sementara kuat pada responden yang memiliki kapal payang dan bagan serta sebagai pemilik kapal. Sejalan dengan itu, untuk mengukur modal ketiga yaitu modal sosial, meliputi kepercayaan, jaringan sosial, dan norma sosial. Responden dilihat sebagai bagian dari rumahtangga nelayan, dan memiliki hubungan dengan tetangga, maupun staf pemerintahan di komunitasnya di tengah norma sosial terkait pangan.

Definisi operasional dari variabel terakhir yaitu ketahanan pangan sebagai kondisi terpenuhinya kebutuhan pangan bagi setiap anggota rumahtangga nelayan ditandai dengan adanya ketersediaan pangan, kemudahan akses pangan, dan ketercukupan konsumsi pangan pada rumahtangga nelayan. Pengukuran ketiga variabel terdiri dari 12 pertanyaan yang didasarkan pada 2 pilihan jawaban, yaitu Ya dan Tidak. Perhitungan skor tiap variabel dilakukan dengan menjumlahkan tiap skor dari tiap indikator yang kemudian membagi responden ke dalam kelompok kategori kuat dan lemah untuk tiga variabel tersebut dengan mengacu pada tingkat minimum penguasaan suatu domain keterampilan yaitu 80\% (Anastasi \& Urbina, 1997).

\section{Metode Analisis}

Teknik analisis data untuk menjawab tujuan penelitian pertama untuk menganalisis mengenai pengaruh modal pada tindakan memilih pangan, yaitu Uji beda proporsi Mann-Whitney U Test. Uji non-parametrik ini digunakan untuk menguji dua atau lebih kelompok yang berbeda pada suatu variabel dependent dengan menggunakan rank dibandingkan menggunakan data yang terobservasi (Singh, 2007). Teknik ini digunakan untuk melihat motif memilih pangan dengan pemenuhan indikator ketahanan pangan berdasarkan dua (2) kelompok yang dianggap berbeda populasi dalam kepemilikan modal budaya, ekonomi, dan sosial pada responden. Dua kelompok tersebut adalah Kelompok rendah dan tinggi untuk modal budaya serta Kelompok lemah dan kuat untuk modal ekonomi dan sosial.

$$
U=\frac{n_{1} n_{2}+n_{1}\left(n_{1}+1\right)-R_{1}}{2}
$$

Keterangan/Remarks:

$\mathrm{n}_{1}=$ Jumlah item dalam kelompok 1/The number of items in group 1

$\mathrm{n}_{2}=$ Jumlah item dalam kelompok 2/The number of items in group 2

$R_{1}=$ Jumlah rank dalam kelompok 1/The number of rank in group 1

Hipotesis yang diberlakukan dalam uji ini adalah sebagai berikut/Hypothesis imposed in this test are:

$\mathrm{Ho}=$ Dua kelompok berasal dari populasi yang identik/ The two group come from identical populations

$\mathrm{Ha}=$ Dua kelompok berasal dari populasiyang berbeda/ The two group come from different populations

Pengambilan keputusan menurut/decision making: $p<0.05$ maka tolak $\mathrm{Ho} / p<0.05$ then reject $\mathrm{Ho}$ $p>0.05$ maka terima $\mathrm{Ho} / p>0.05$ then accept $\mathrm{Ho}$

Sementara itu teknik analisis, yaitu Spearman's rho, digunakan untuk menjawab tujuan kedua yaitu mengidentifikasi hubungan antara perilaku memilih pangan dengan ketahanan pangan.

Rumus Spearman's Rho (Singh, 2007) adalah sebagai berikut:

$$
r_{\rho=1}-\frac{6 \Sigma^{2}}{N\left(N^{2}-1\right)}
$$

Keterangan/Remarks:

$$
\begin{aligned}
r_{\rho}= & \text { Korelasi Spearman/Spearman correlation } \\
\mathrm{D}= & \text { Perbedaan antara kedua rank, yaitu rank skor } \\
& \mathrm{X} \text { dan skor } \mathrm{Y} / \text { The difference between the second } \\
& \text { rank, i.e rank score } \mathrm{X} \text { and score } \mathrm{Y} \\
\mathrm{N}= & \text { Jumlah pengukuran dari rank/The number of } \\
& \text { measurements of the rank }
\end{aligned}
$$


Sejalan dengan itu, data dari wawancara dianalisis secara deskriptif dengan metode ilustrasi untuk mendukung hasil penelitian. Proses yang dilakukan adalah melihat adanya pola dari perilaku, obyek, sistem keyakinan, dan hubungan di antaranya pada data untuk kemudian diinterpretasi menggunakan tema, konsep, maupun teori dan terkait dengan konteks budaya dan sejarah (Newman, 2014).

\section{HASIL DAN PEMBAHASAN}

\section{Karakteristik Responden}

Responden dalam penelitian ini berjumlah 30 responden terdiri dari 22 laki-laki dan 8 perempuan. Pada umumnya usia responden tergolong pada kelompok usia madya (40-60 tahun) dengan persentase sebesar $60 \%$ dari keseluruhan responden (Tabel 1). Semua responden merupakan rumah tangga nelayan dari suku Minang. Laki-laki dalam suku ini juga ikut berperan dalam pemilihan maupun pengolahan (memasak) bahan pangan untuk keluarganya ketika tidak sedang melaut. Mereka juga tidak segan untuk membantu isteri yang memasak untuk keluarganya.

Meski Djunaidah \& Nurmalia (2018) menemukan bahwa banyak perempuan di pesisir yang berkontribusi pada pendapatan rumahtangga dengan bekerja, namun dalam penelitian ini nampak $17 \%$ yang sebagai pedagang (manggaleh dalam bahasa Minang). Kebanyakan dari mereka berperan sebagai ibu Rumah Tangga yang menunggu suaminya melaut dengan menunggu di rumah dan juga menyiapkan pangan untuk dikonsumsi keluarga. Manggaleh merupakan kegiatan berdagang dengan membuka warung makan khas dari Padang atau membuka warung kopi di tepi pantai. Warung kopi di tepi pantai menjadi tempat membangun relasi dan tempat berkumpul sesama nelayan setelah pulang dari kegiatan melaut.

Data memperlihatkan bahwa sekitar $70 \%$ responden menempuh pendidikan dasar di SD dan SMP, dan sebanyak 6,7\% yang berpendidikan Diploma dan Sarjana. Sebanyak 70\% responden yang jumlah anggota rumahtangganya berjumlah 4-6 orang. Jenis kapal yang digunakan nelayan dalam penelitian pada umumnya yaitu longtel (perahu tanpa motor) sebanyak $70 \%$ atau 21 orang, payang (perahu motor) sebanyak $23,3 \%$ dan kapal bagan sebanyak $6,7 \%$ atau 2 orang. Data ini menunjukkan kecenderungan yang sama bahwa terdapat responden yang berada dalam lapisan bawah-menengah (70\%) sebagai ABK yang masih mengandalkan dalam melaut sementara sisanya adalah pemilik kapal. Sementara itu fenomena perubahan iklim semakin terasa dalam masa peralihan mendekati masa paceklik di lokasi sehingga mempengaruhi waktu kerja responden menjadi semakin sulit menentukan waktu melaut dan hasil tangkapan yang mulai kurang maksimal. Konteks spesifik pada komunitas nelayan inilah yang akan menjadi cakupan

Tabel 1. Karakteristik responden penelitian di Desa Marunggi dan Desa Taluk, 2018.

Table 1. Characteristics respondent penelitian in Marunggi and Taluk VIIlage, 2018.

\begin{tabular}{cllc}
\hline \multirow{2}{*}{ No } & \multirow{2}{*}{ Variabel/Variable } & \multicolumn{1}{c}{ Indikator/Indicator } & $\begin{array}{c}\text { Persentase/ } \\
\text { Percentage (\%) }\end{array}$ \\
\hline 1 & Jenis kelamin/gender & Laki-laki/male & 73.3 \\
& & Perempuan/female & 26.7 \\
\hline 2 & Usia/age & $20-39$ tahun & 26.7 \\
& & $40-60$ tahun & 60.0 \\
& & Lebih dari 60 tahun/ more than 60 years & 13.3 \\
\hline 3 & Tingkat pendidikan/ & SD/primary school & 43.3 \\
& level of education & SMP/junior high school & 26.7 \\
& & SMA/senior high school & 16.7 \\
& & Diploma/diploma & 6.7 \\
& & Sarjana/bachelor & 6.7 \\
\hline 4 & Jumlah anggota rumah tangga/ & 4-6 orang/person & 70.0 \\
& number of family members & 7-9 orang/person & 30.0 \\
\hline 5 & Jenis kapal/ship type & Longtel/longtel & 70.0 \\
& & Payang/payang & 23.3 \\
& & Bagan/bagan & 6.7 \\
\hline 6 & Status/status & Anak buah kapal/the crew ship & 70 \\
& & Induak samang/induak samang & 30 \\
\hline
\end{tabular}


pembahasan mengenai perilaku pemilihan dan konsumsi pangannya.

\section{Motif dalam Memilih Pangan berdasarkan Aspek Modal}

Empat motif dalam memilih pangan yang diukur dari responden terdiri dari motif kebiasaan (budaya), harga (ekonomi), pengaruh sosial (sosial), dan kesehatan. Data pada Gambar 1. menunjukkan bahwa motif yang paling kuat dan menjadi pertimbangan responden dalam tindakan pemilihan pangan adalah kebiasaan, kemudian disusul oleh harga, kesehatan, dan pengaruh orang lain (Gambar 1). Hasil ini sejalan dengan Warsilah (2013) yang menyatakan adanya peran kebiasaan pangan masyarakat perdesaan pesisir dalam mendukung ketahanan pangan di Kabupaten Minahasa Utara.

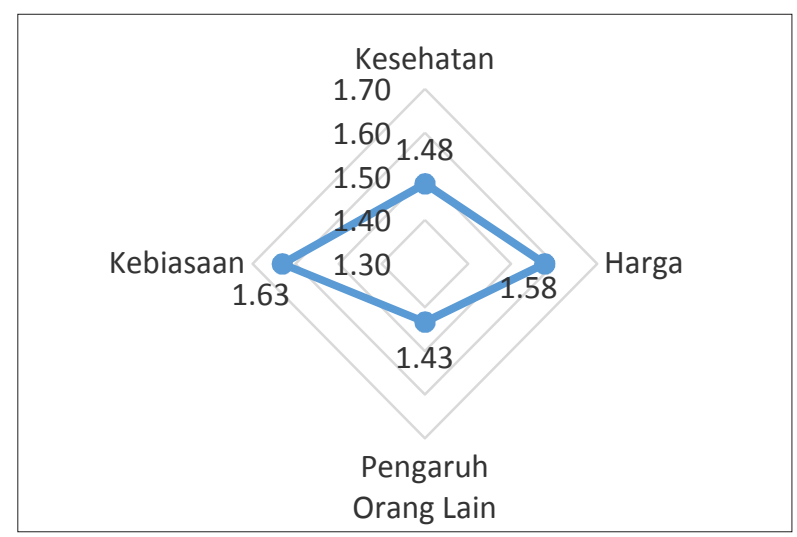

Gambar 1. Motif Sosio-Ekonomi-Budaya-Kesehatan yang mempengaruhi Perilaku Pemilihan Pangan di Desa Marunggi dan Taluk, tahun 2018.

Figure 1. Socio-Economic-Cultural-Health Motives that influence Food Choices Behavior in Marunggi and Taluk Village, 2018.

Jika berdasarkan modal, responden terbagi secara tidak merata berdasarkan modal yang dimilikinya (Tabel 2). Sebanyak $80 \%$ responden memiliki modal budaya yang rendah yang dicirikan memiliki latar belakang pendidikan dasar hingga SMA sementara responden yang memiliki modal ekonomi lemah dengan aset kapal penangkap ikan berupa longtel dan statusnya anak buah kapal (ABK) sebanyak $57 \%$.

Sebanyak $77 \%$ responden memiliki modal sosial yang cenderung lemah. Berdasarkan komponen penyusunnya, maka modal sosial responden tergolong kuat pada kepercayaan sementara lemah pada jaringan dan norma. Di antara responden nampak adanya kepercayaan yang tinggi untuk dapat saling membantu jika ada yang kekurangan pangan, berupa kepercayaan dalam pemberian hutang di warung atau meminjam uang kepada saudara, berbeda halnya dengan responden dengan jaringan sosial yang sempit yang dicirikan dengan tidak banyak memiliki hubungan akrab dengan tenaga kesehatan seperti bidan desa dan tidak terlalu mengenal staf dari pemerintah seperti saat menerima bantuan beras, hanya kerabat dekat yang memiliki akses jaringan dalam memperoleh bantuan. Jaringan sosial yang luas dimiliki oleh warga yang di"tetuakan" atau yang dianggap dapat mengayomi warga sehingga mereka yang dipercayai tersebut memudahkan dalam hubungan sosial dengan warga lainnya.

\section{Motif dan Indikator Perilaku Memilih Pangan Menurut Modal Budaya}

Data memperlihatkan bahwa motif harga dan kebiasaan menjadi yang paling banyak dipertimbangkan oleh dua kelompok responden baik yang memiliki latar belakang pendidikan rendah maupun tinggi dalam perilaku memilih pangannya (Tabel 3). Hasil ini sedikit berbeda dengan hasil penelusuran alasan pemilihan pangan pada mahasiswa oleh Puspadewi \& Briawan (2014) yang menyatakan bahwa alasan utama terdiri dari kandungan alami pangan, kesehatan, dan harga.

Tabel 2. Sebaran responden berdasarkan kepemilikan modal di Desa Marunggi dan Desa Taluk Tahun 2018.

Table 2. Respondents Distribution Based on Capitals in Marunggi and Taluk VIllage, 2018.

\begin{tabular}{|c|c|c|c|c|c|c|c|c|c|}
\hline \multirow[t]{2}{*}{$\begin{array}{l}\text { Responden/ } \\
\text { Respondents }\end{array}$} & \multicolumn{3}{|c|}{$\begin{array}{l}\text { Modal Budaya/ } \\
\text { Culture Capital }\end{array}$} & \multicolumn{3}{|c|}{$\begin{array}{l}\text { Modal Ekonomi/ } \\
\text { Economic Capital }\end{array}$} & \multicolumn{3}{|c|}{$\begin{array}{l}\text { Modal Sosial/ } \\
\text { Social Capital }\end{array}$} \\
\hline & $\begin{array}{l}\text { Rendah/ } \\
\text { Low }\end{array}$ & $\begin{array}{c}\text { Tinggi/ } \\
\text { High }\end{array}$ & $\begin{array}{l}\text { Total/ } \\
\text { Total }\end{array}$ & $\begin{array}{l}\text { Lemah/ } \\
\text { Low }\end{array}$ & $\begin{array}{l}\text { Kuat/ } \\
\text { Strong }\end{array}$ & $\begin{array}{l}\text { Total/ } \\
\text { Total }\end{array}$ & $\begin{array}{l}\text { Lemah/ } \\
\text { Low }\end{array}$ & $\begin{array}{l}\text { Kuat/ } \\
\text { Strong }\end{array}$ & $\begin{array}{l}\text { Total } \\
\text { Total }\end{array}$ \\
\hline $\begin{array}{l}\text { Frekuensi/ } \\
\text { Frequency }\end{array}$ & 24 & 6 & 30 & 17 & 13 & 30 & 23 & 7 & 30 \\
\hline $\begin{array}{l}\text { Persentase/ } \\
\text { Percentage } \%\end{array}$ & 80.0 & 20.0 & 100.0 & 56.7 & 43.3 & 100.0 & 76.7 & 23.3 & 100.0 \\
\hline
\end{tabular}


Tabel 3. Rata-Rata Skor Motif Pemilihan Pangan Berdasarkan Modal Budaya di Desa Marunggi dan Desa Taluk Tahun 2018.

Table 3. Average Score of Motives in Food Choices Based on Cultural Capital in Marunggi and Taluk VIIlage, 2018.

\begin{tabular}{lccccc}
\hline \multirow{2}{*}{$\begin{array}{c}\text { Motif memilih pangan/ } \\
\text { Motives of Food Choices }\end{array}$} & \multicolumn{2}{c}{ Modal Budaya/Cultural Capital } & \multirow{2}{*}{ Total } & \multirow{2}{*}{$\mathbf{p}$} \\
\cline { 2 - 3 } & Rendah/Low & Tinggi/High & & \\
\cline { 2 - 4 } & Mean \pm SD & Mean \pm SD & Mean \pm SD & \\
\hline Kesehatan/Health & $1.52 \pm 0.34$ & $1.33 \pm 0.26$ & $1.48 \pm 0.33$ & 0.22 \\
Harga/Price & $1.64 \pm 0.31$ & $1.33 \pm 0.37$ & $1.58 \pm 0.34$ & 0.05 \\
Pengaruh orang lain/Other people influence & $1.48 \pm 0.23$ & $1.30 \pm 0.21$ & $1.43 \pm 0.24$ & 0.05 \\
Kebiasaan/Habits & $1.64 \pm 0.14$ & $1.60 \pm 0.12$ & $1.63 \pm 0.14$ & 0.43 \\
\hline Total empat motif/Sum of motives & $1.58 \pm 0.09$ & $1.43 \pm 0.05$ & $1.55 \pm 0.10$ & 0.00 \\
\hline
\end{tabular}

Berdasarkan modal budaya, terlihat ada dukungan data mengenai perbedaan perilaku pemilihan pangan yang berdasarkan empat motif (kesehatan, harga, pengaruh orang lain, dan kebiasaan) antara responden yang memiliki latar belakang pendidikan rendah dan tinggi $(p<0,05)$. Hal ini menunjukkan bahwa perilaku pemilihan pangan pada responden yang memiliki latar belakang pendidikan rendah lebih dipengaruhi oleh adanya 4 motif yang bersifat sosio-ekonomibudaya-kesehatan dibanding responden yang lebih tinggi latar belakang pendidikannya.

Mengacu pada uji beda proporsi pada item di tiap motif yaitu kesehatan dan harga (4), Pengaruh orang lain (Tabel 6), dan Kebiasaan (Tabel 8) maka nampak bahwa responden dari modal budaya rendah lebih banyak menampilkan perilaku pangannya pada perilaku dengan mempertimbangkan harga ketika membeli pangan (motif Harga), mempertimbangkan pengaruh tetangga (motif Pengaruh orang lain), dan mengolah pangan yang sudah disosialisasikan oleh orangtua (motif Kebiasaan) dibandingkan responden dengan modal budaya tinggi $(p<0,05)$.

Berdasarkan motif harga, responden yang memiliki modal budaya lemah lebih mempertimbangkan harga agar dapat terjangkau (murah) bagi keluarganya dibandingkan responden dari modal budaya tinggi $(p<0,05)$. Data menunjukkan masih banyaknya responden yang memilih harga yang terjangkau (murah) untuk mendapatkan jumlah pangan yang lebih banyak dibandingkan yang berkualitas namun dengan harga yang lebih mahal.

Sementara itu kuatnya motif Kebiasaan pada responden terlihat dari dikonsumsinya pangan yang disosialisasikan oleh keluarga (orangtuanya)

Tabel 4. Perbandingan Nilai Mean Motif Kesehatan dan Harga Dalam Memilih Pangan Berdasarkan Modal di Desa Marunggi dan Desa Taluk Tahun 2018.

Table 4. Mean Score Comparison of Health and Price Motives in Food Choices Based on Capitals In Marunggi and Taluk VIIlage, 2018.

\begin{tabular}{|c|c|c|c|c|c|c|c|c|c|}
\hline \multirow{2}{*}{$\begin{array}{l}\text { Motif dan Indikatorl } \\
\text { Motive and Indicators }\end{array}$} & \multicolumn{3}{|c|}{$\begin{array}{c}\text { Modal Budaya/cultural } \\
\text { capital }\end{array}$} & \multicolumn{3}{|c|}{$\begin{array}{l}\text { Modal Ekonomi/ } \\
\text { economic capital }\end{array}$} & \multicolumn{3}{|c|}{$\begin{array}{l}\text { Modal Sosial / } \\
\text { social capital }\end{array}$} \\
\hline & $\begin{array}{l}\text { Rendah/ } \\
\text { low }\end{array}$ & $\begin{array}{l}\text { Tinggi/ } \\
\text { high }\end{array}$ & $\mathrm{p}$ & $\begin{array}{l}\text { Lemah/ } \\
\text { weak }\end{array}$ & $\begin{array}{l}\text { Kuat/ } \\
\text { strong }\end{array}$ & $p$ & $\begin{array}{l}\text { Rendah/ } \\
\text { low }\end{array}$ & $\begin{array}{l}\text { Tinggi / } \\
\text { high }\end{array}$ & p \\
\hline \multicolumn{10}{|l|}{ Kesehatan/health } \\
\hline $\begin{array}{l}\text { Keseimbangan nutrisi/ } \\
\text { nutritional balance }\end{array}$ & 1.38 & 1.00 & .078 & 1.29 & 1.31 & .937 & 1.17 & 1.71 & .007 \\
\hline $\begin{array}{l}\text { Menghindari MSG/Avoid } \\
\text { MSG }\end{array}$ & 1.67 & 1.67 & 1.000 & 1.76 & 1.54 & .200 & 1.70 & 1.57 & .548 \\
\hline \multicolumn{10}{|l|}{ Harga/price } \\
\hline $\begin{array}{l}\text { Harga terjangkau/ } \\
\text { affordable price }\end{array}$ & 1.75 & 1.67 & .685 & 1.82 & 1.62 & .209 & 1.74 & 1.71 & .898 \\
\hline $\begin{array}{l}\text { Harga tidak boleh tinggi/ } \\
\text { price could not be high }\end{array}$ & 1.42 & 1.17 & .264 & 1.35 & 1.38 & .861 & 1.35 & 1.43 & .703 \\
\hline $\begin{array}{l}\text { Membeli pangan saat } \\
\text { harga rendah/ } \\
\text { buy food when its cheap }\end{array}$ & 1.75 & 1.17 & .009 & 1.76 & 1.46 & .093 & 1.65 & 1.57 & .703 \\
\hline
\end{tabular}


$(p<0,05)$, seperti gulai dengan pangan berasal dari ikan yang memiliki kandungan santan dengan rasa yang pedas, memuat bahan rempah dan sambal. Cara makan responden biasanya mencampur makanan bersantan dengan sayuran, misalnya lauk gulai ikan dicampur dengan daun singkong. Kebiasaan pangan ini telah secara turun temurun disosialisasikan dalam keluarga. Proses pengenalan pangan dalam keluarga dimulai dari kecil, remaja, dewasa, hingga ke generasi selanjutnya. Seperti pada anggota keluarga yang telah remaja beranjak dewasa diharapkan dapat membantu orangtua dalam memasak didapur, melalui proses itulah pengenalan mengenai rempah-rempah khas minang dapat diteruskan. Selain itu, kebiasaan pangan juga didapat dari tasyakuran, acara adat, ataupun acara baralek anak (pernikahan), para warga, tetangga terdekat, serta sanak saudara masak bersama dalam menghidangkan pangan untuk nantinya dimakan bersama dalam acara. Melalui kegiatan masak bergotongroyong tersebut maka diketuai oleh sesepuh yang dianggap sudah ahli dalam memasak dan biasanya diikuti oleh para ibu yang dapat melihat secara langsung proses pembuatan pangan. Kearifan lokal seperti ini mampu menguatkan kebiasaan pangan dan dapat mendapat menjadi identitas pangan suatu daerah.

\section{Motif dan Indikator Dalam Perilaku Memilih Pangan Menurut Modal Ekonomi}

Data menggambarkan bahwa peran modal ekonomi tidak ada perbedaan yang signifikan diberikan tiap motif pada perilaku pemilihan pangan. Terlihat bahwa motif Kebiasaan memiliki kontribusi terbesar dalam mempengaruhi perilaku memilih pangan pada kedua kategori responden baik lemah $(1,66 \pm 0,15)$ maupun kuat $(1,60 \pm$ 0,11 ) (Tabel 5). Responden memiliki kebiasaan makan sebanyak 3 kali sehari, membuat makanan yang menjadi kebiasaan pangan yang dibuat keluarga pada suatu waktu tertentu dan membuat pangan yang jenis pangannya disosialisasikan dari orangtua mereka, seperti gulai yang diberikan cabai atau sambal.

Namun modal ekonomi tampak mampu memberi perbedaan yang siginifikan pada perilaku pemilihan pangan responden yang berdasar empat motif (sosio-ekonomi-budayakesehatan). Responden dengan modal ekonomi lemah dipengaruhi lebih banyak oleh empat motif dalam perilaku dalam pemilihan pangannya dibandingkan responden dengan modal ekonomi kuat $(p<0,05)$. Hal ini menunjukkan bahwa status responden dalam usaha perikanan baik yang memiliki alat tangkap longtel, payang, maupun bagan dan status sebagai ABK dan pemilik kapal dapat mempengaruhi secara berbeda perilaku mereka dalam memilih pangannya berdasarkan empat motif.

Dari uji per item dalam Tabel 5 ditemukan bahwa responden dengan modal ekonomi lemah tampak lebih banyak dipengaruhi oleh orang lain yang berasal dari keluarga sehingga memilih pangan yang disukai anggota keluarga yang lain $(p<0,05)$, misalnya anak, dengan menghidangkan gulai dan sambal.

Pada motif harga, responden dari kelompok modal ekonomi rendah lebih banyak menggunakan pertimbangan tentang harga terjangkau untuk memperoleh lebih banyak bahan pangan dibandingkan responden dari modal ekonomi kuat $(p>0,05)$. Namun data menunjukkan $76.5 \%$ responden dengan modal ekonomi lemah memilih pangan dengan kecenderungan untuk memperoleh jumlah pangan yang banyak

Tabel 5. Rata-Rata Skor Motif Pemilihan Pangan Berdasarkan Modal Ekonomi di Desa Marunggi dan Desa Taluk Tahun 2018.

Table 5. Average Score Of Motives In Food Choices Based On Ecomonic Capital In Marunggi and Taluk VIIlage, 2018.

\begin{tabular}{lcccc}
\hline \multirow{2}{*}{$\begin{array}{l}\text { Motif memilih pangan/ } \\
\text { Motives of Food Choices }\end{array}$} & \multicolumn{2}{c}{ Modal Ekonomi/economic Capital } & \multirow{2}{*}{ Total } & \multirow{2}{*}{$\mathbf{p}$} \\
\cline { 2 - 3 } & Lemah/weak & Kuat/strong & & \\
\cline { 2 - 4 } & Mean \pm SD & Mean \pm SD & Mean \pm SD & \\
\hline Kesehatan/Health & $1.53 \pm 0.28$ & $1.42 \pm 0.40$ & $1.48 \pm 0.33$ & 0.37 \\
Harga/Price & $1.65 \pm 0.32$ & $1.49 \pm 0.35$ & $1.58 \pm 0.34$ & 0.22 \\
Pengaruh orang lain/ & $1.45 \pm 0.25$ & $1.42 \pm 0.24$ & $1.43 \pm 0.24$ & 1.00 \\
Other people influence & & & & \\
Kebiasaan/Habits & $1.66 \pm 0.15$ & $1.60 \pm 0.11$ & $1.63 \pm 0.14$ & 0.19 \\
\hline Total empat motif/Sum of motives & $1.59 \pm 0.90$ & $1.51 \pm 0.10$ & $1.55 \pm 0.10$ & 0.04 \\
\hline
\end{tabular}


Tabel 6. Perbandingan Nilai Mean Motif Pengaruh Orang Lain Dalam Memilih Pangan Berdasarkan Modal di Desa Marunggi dan Desa Taluk Tahun 2018.

Table 6. Mean Score Comparison of Other People Influences Motives in Food Choices Based on Capitals in Marunggi and Taluk VIllage, 2018.

\begin{tabular}{|c|c|c|c|c|c|c|c|c|c|}
\hline \multirow{2}{*}{$\begin{array}{l}\text { Motif dan Indikator/ } \\
\text { Motive and Indicators }\end{array}$} & \multicolumn{3}{|c|}{$\begin{array}{l}\text { Modal Budaya/ } \\
\text { Cultural Capital }\end{array}$} & \multicolumn{3}{|c|}{$\begin{array}{l}\text { Modal Ekonomi// } \\
\text { Economic Capital }\end{array}$} & \multicolumn{3}{|c|}{$\begin{array}{l}\text { Modal Sosial I } \\
\text { Social Capital }\end{array}$} \\
\hline & $\begin{array}{l}\text { Rendah/ } \\
\text { Low }\end{array}$ & $\begin{array}{c}\text { Tinggi/ } \\
\text { High }\end{array}$ & $p$ & $\begin{array}{l}\text { Lemah/ } \\
\text { Weak }\end{array}$ & $\begin{array}{l}\text { Kuat/ } \\
\text { Strong }\end{array}$ & p & $\begin{array}{l}\text { Rendah/ } \\
\text { Low }\end{array}$ & $\begin{array}{c}\text { Tinggi / } \\
\text { High }\end{array}$ & $p$ \\
\hline $\begin{array}{l}\text { Bukan rencana sendiri/ } \\
\text { Not by own self plan }\end{array}$ & 1.33 & 1.33 & 1.000 & 1.29 & 1.38 & .608 & 1.26 & 1.57 & .133 \\
\hline $\begin{array}{l}\text { Pangan kesukaan keluarga/ } \\
\text { Family's favorite food }\end{array}$ & 1.63 & 1.67 & .852 & 1.82 & 1.38 & .015 & 1.65 & 1.57 & .703 \\
\hline $\begin{array}{l}\text { Ajakan tetangga/Neigbours } \\
\text { persuasiveness }\end{array}$ & 1.50 & 1.00 & .028 & 1.47 & 1.31 & .375 & 1.43 & 1.29 & .488 \\
\hline $\begin{array}{l}\text { Pengaruh dari televisi/Influences } \\
\text { of television }\end{array}$ & 1.50 & 1.17 & .147 & 1.35 & 1.54 & .318 & 1.35 & 1.71 & .092 \\
\hline $\begin{array}{l}\text { Agar terlihat mampu dibandingkan } \\
\text { warga lain/To make look more } \\
\text { capable than others }\end{array}$ & 1.42 & 1.17 & .264 & 1.29 & 1.46 & .354 & 1.26 & 1.71 & .032 \\
\hline
\end{tabular}

dari suatu biaya yang dikeluarkan yang dapat diakibatkan oleh pendapatan kurang pasti dan kurang memadai dari tangkapan dari status mereka sebagai nelayan dan hanya sebagian kecil yang memiliki pekerjaan sampingan. Responden mengaku tidak memiliki uang untuk membeli pangan pokok meskipun harga bahan pangan pokok dan bahan pangan lauk masih dalam batas normal. Hal ini sejalan dengan yang diungkapkan oleh Pechey \& Monsivais (2016) bahwa kelas sosial yang lebih tinggi mempunyai ketersediaan pangan dan pengeluaran yang lebih banyak untuk membeli dan memilih pangan yang lebih sehat dibandingkan dengan kelas sosial yang lebih rendah. Hal ini ditambah lagi dengan adanya kepercayaan pemilik warung bahan pangan pada responden bermodal ekonomi kuat untuk berhutang dalam mengakses pangan dibandingkan pada responden dengan modal ekonomi lemah. Bagi responden dengan modal ekonomi lemah, hutang dari patronnya dapat digunakan sebagai modal untuk menjalankan aktivitas penangkapan ikannya seperti perahu, mesin, dan alat tangkap (Muhartono \& Nurlaili, 2018).

Motif kesehatan nampak mempengaruhi perilaku pemilihan pangan responden dengan modal ekonomi yang kuat terlihat lebih memperhatikan kandungan gizi yang ada di setiap pangan yang dimakan $(p>0,05)$. Responden dengan modal ekonomi kuat memiliki lebih banyak pilihan dalam menentukan pola hidup sehat. Meski didukung oleh pendapatan yang mencukupi, kondisi kesehatan responden juga mempengaruhi pilihan pangannya, seperti mengurangi makanan yang digoreng dan mengandung zat penyedap makanan. Seperti pernyataan salah satu responden dari modal ekonomi kuat berikut ini:

"sekarang ngindar gorengan, minyakminyak juga...ada kolesterol. jadi dikurangilah sekarang." (MS, Laki-laki, 67 tahun)."

\section{Motif dan Indikator Dalam Perilaku Memilih Pangan Menurut Modal Sosial}

Data memperlihatkan kontribusi terbesar dalam mempengaruhi perilaku memilih pangan responden dengan modal sosial lemah adalah kebiasaan $(1,64 \pm 0,15)$, sementara bagi responden dengan modal sosial kuat adalah kesehatan $(1,64 \pm 0,38)$. (Tabel 7$)$. Empat motif yaitu Sosial, Ekonomi, Budaya, dan, Kesehatan jika secara bersamaan diuji maka tidak membedakan perilaku pemilihan pangan antar responden baik dengan modal sosial yang lemah maupun kuat $(p>0,05)$. Hasil ini menunjukkan bahwa modal sosial yang merupakan kekuatan bagi responden untuk bekerjasama dalam komunitas tidak berbeda antara yang memiliki modal sosial kuat dan lemah dalam motif memilih pangannya. Kepercayaan, jejaring, dan norma di komunitas baik yang lemah maupun kuat pada rumahtangga responden berdampak tidak berbeda pada akumulasi tiap motif pemilihan pangannya. Hal ini dapat menggambarkan bahwa kepercayaan antar responden, jejaring yang dimiliki, maupun aturan dalam komunitas tidak membagi pemilihan pangan responden berdasarkan alasan untuk menjaga kesehatan, keuangan, kebiasaan, maupun adanya pengaruh orang lain. 
Tabel 7. Rata-Rata Skor Motif Pemilihan Pangan Berdasarkan Modal Sosial di Desa Marunggi dan Desa Taluk Tahun 2018.

Table 7. Average Score of Motives in Food Choice Based on Social Capital in Marunggi and Taluk VIIlage, 2018.

\begin{tabular}{lccccc}
\hline \multirow{2}{*}{$\begin{array}{c}\text { Motif memilih pangan/ } \\
\text { Motives of Food Choices }\end{array}$} & \multicolumn{2}{c}{ Modal Budaya/Cultural Capital } & \multirow{2}{*}{ Total } & \multirow{p}{*}{$\mathbf{p}$} \\
\cline { 2 - 4 } & Lemah/Low & Kuat/High & & \\
\cline { 2 - 4 } & Mean \pm SD & Mean \pm SD & Mean \pm SD & \\
\hline Kesehatan/Health & $1.43 \pm 0.31$ & $1.64 \pm 0.38$ & $1.48 \pm 0.33$ & 0.15 \\
Harga/Price & $1.54 \pm 0.37$ & $1.57 \pm 0.35$ & $1.58 \pm 0.34$ & 0.87 \\
Pengaruh orang lain/Other people influence & $1.39 \pm 0.23$ & $1.57 \pm 0.24$ & $1.43 \pm 0.24$ & 0.12 \\
Kebiasaan/Habits & $1.64 \pm 0.15$ & $1.63 \pm 0.10$ & $1.63 \pm 0.14$ & 0.88 \\
\hline Total empat motif/sum of motives & $1.53 \pm 0.10$ & $1.60 \pm 0.09$ & $1.55 \pm 0.10$ & 0.11 \\
\hline
\end{tabular}

Meskipun begitu pengaruh modal sosial masih dapat ditemui pada responden dengan adanya perbedaan dalam motif memilih pangan jika mengacu pada hasil uji hubungan dilakukan berdasarkan item di tiap motif memilih pangan (Tabel 4, 6, dan 8). Terlihat bahwa keseimbangan nutrisi (motif Kesehatan), tujuan agar terlihat mampu dibandingkan warga lain (motif Pengaruh orang lain), dan pengolahan bahan segar (motif Kebiasaan) dipengaruhi oleh modal sosial responden $(p<0,05)$.

Berdasarkan aspek kesehatan, responden dengan modal sosial kuat lebih mengutamakan keseimbangan gizi dari pangan baik yang terdiri dari beras/nasi, lauk pauk, sayur dan buahnya dibandingkan dengan responden yang memiliki modal sosial lemah. Hal ini berbeda dengan responden dengan modal sosial rendah yang menjadikannya sebagai responden yang kebanyakan mengkonsumsi gulai, menjadikannya sebagai sayur dan lauk-pauk, seperti yang diungkapkan salah satu responden dengan modal sosial rendah sebagai berikut:

"kebiasaan makan gulai, makan gulai itu sekalian sayur, gulai sambal, gorengan dikurangi..." (AZ, Laki-laki, 38 tahun)

Kebanyakan responden yang memiliki modal sosial lemah tampak tidak membeli buah-buahan dan sayur sebagai diet pada pangan sehat yang harus dikonsumsi. Hal ini sejalan pandangan yang menyatakan bahwa komunitas lokal di pedesaan memiliki pola diet yang tidak sehat dengan kurang mengkonsumsi buah dan sayur (Henryks, Brimblecombe, \& Bidstrup, 2017). Kebiasaan pangan berupa pola makan yang mengandung gizi tidak berimbang berupa protein yang berasal dari pangan yang dipilih oleh responden dengan modal sosial lemah. Salah satu responden bermodal sosial lemah menyatakan asal pangan protein hewaninya hanya berasal dari ikan karena tidak menyukai daging, yang kutipannnya sebagai berikut:

"suami jarang makan daging, tidak suka makan daging. Dia sukanya makan ikan dan ayam. Tapi kalau daging sapi atau daging kerbau tidak makan.." (HN, Perempuan, 43 tahun)

Tampak bahwa responden dengan modal sosial lemah mengkonsumsi ikan yang ada di sekitar tempat tinggal mereka dan lebih banyak mengolah pangan dari bahan segar seperti ikan dibandingkan yang modal sosial kuat $(p<0,05)$. Responden dari kategori modal sosial lemah ini akan mengkonsumsi telur atau mi instan jika tidak memiliki ikan sebagai bahan pangannya. Hal ini menunjukkan bahwa jaringan sosial dari responden kelompok dengan modal sosial kuat dapat berperan dalam memberikan pilihan pangan non-ikan dari luar desa, seperti bahan daging ayam, daging sapi, telur maupun makanan instant. Hal ini dapat didukung oleh kuatnya modal sosial yang dimiliki oleh responden pada musim peralihan dibandingkan responden modal sosial lemah terutama untuk komponen kepercayaan dan jaringan sosial sehingga banyak percaya untuk berhubungan dengan warga lainnya dan berhubungan dengan etnis yang sama di luar desa. Motif Kesehatan ini tampak berinteraksi dengan motif Pengaruh sosial pada responden dengan modal sosial luas ini dibandingkan dengan responden bermodal sosial lemah $(p<0,05)$. Responden dengan modal sosial luas tampak menjadikan bahan pangan mereka yang memperhatikan gizi berimbang menjadi sumber perhatian agar terlihat mampu dari warga lainnya. 
Tabel 8. Perbandingan Nilai Mean Motif Kebiasaan Dalam Memilih Pangan Berdasarkan Modal di Desa Marunggi dan Desa Taluk tahun 2018.

Table 8. Mean Score Comparison of Habit Motives in Food Choices Based on Capitals in Marunggi and Taluk VIIlage, 2018.

\begin{tabular}{|c|c|c|c|c|c|c|c|c|c|}
\hline \multirow{2}{*}{$\begin{array}{l}\text { Motif dan Indikator/ } \\
\text { Motive and Indicators }\end{array}$} & \multicolumn{3}{|c|}{$\begin{array}{l}\text { Modal Budaya/ } \\
\text { Cultural Capital }\end{array}$} & \multicolumn{3}{|c|}{$\begin{array}{c}\text { Modal Ekonomi/ Economic } \\
\text { Capital }\end{array}$} & \multicolumn{3}{|c|}{$\begin{array}{l}\text { Modal Sosial I } \\
\text { Social Capital }\end{array}$} \\
\hline & $\begin{array}{l}\text { Rendah/ } \\
\text { Low }\end{array}$ & $\begin{array}{l}\text { Tinggi/ } \\
\text { High }\end{array}$ & p & $\begin{array}{l}\text { Lemah/ } \\
\text { Weak }\end{array}$ & $\begin{array}{l}\text { Kuat// } \\
\text { Strong }\end{array}$ & $p$ & $\begin{array}{l}\text { Rendah/ } \\
\text { Low }\end{array}$ & $\begin{array}{c}\text { Tinggi / } \\
\text { High }\end{array}$ & p \\
\hline $\begin{array}{l}\text { Makan } 3 \text { kali sehari/ } \\
\text { Eat } 3 \text { times a day }\end{array}$ & 1.54 & 1.67 & .587 & 1.47 & 1.69 & .232 & 1.61 & 1.43 & .408 \\
\hline $\begin{array}{l}\text { Konsumsi ikan yang } \\
\text { banyak di lokasi/ } \\
\text { Consumption according } \\
\text { to those in location }\end{array}$ & 1.63 & 1.83 & .341 & 1.76 & 1.54 & .200 & 1.74 & 1.43 & .133 \\
\hline $\begin{array}{l}\text { Mengolah bahan segar/ } \\
\text { Processing fresh } \\
\text { ingredients }\end{array}$ & 1.79 & 2.00 & .229 & 1.88 & 1.77 & .418 & 1.91 & 1.57 & .037 \\
\hline $\begin{array}{l}\text { Mengolah pangan yang } \\
\text { disosialisasikan orangtua/ } \\
\text { According to what } \\
\text { parents socialize }\end{array}$ & 1.88 & 1.50 & .043 & 1.76 & 1.85 & .587 & 1.83 & 1.71 & .524 \\
\hline $\begin{array}{l}\text { Mengolah pangan yang } \\
\text { menjadi menu keluarga } \\
\text { pada waktu tertentu/Food } \\
\text { processing at a certain } \\
\text { time }\end{array}$ & 1.54 & 1.17 & .105 & 1.41 & 1.54 & .498 & 1.39 & 1.71 & .140 \\
\hline $\begin{array}{l}\text { Melakukan penghangatan } \\
\text { kembali makanan/ } \\
\text { Re-warming food }\end{array}$ & 1.46 & 1.17 & .200 & 1.47 & 1.31 & .375 & 1.35 & 1.57 & .299 \\
\hline $\begin{array}{l}\text { Mengkonsumsi makanan } \\
\text { berlemak/Eating fatty } \\
\text { foods }\end{array}$ & 1.75 & 1.83 & .671 & 1.82 & 1.69 & .408 & 1.74 & 1.86 & .525 \\
\hline $\begin{array}{l}\text { Tidak memasak resep } \\
\text { makanan baru/Not } \\
\text { cooking new foos recipe }\end{array}$ & 1.54 & 1.67 & .587 & 1.71 & 1.38 & .084 & 1.57 & 1.57 & .977 \\
\hline $\begin{array}{l}\text { Memiliki pantangan } \\
\text { makanan dari keluarga/ } \\
\text { Have food cuts }\end{array}$ & 1.63 & 1.50 & .583 & 1.65 & 1.54 & .554 & 1.57 & 1.71 & .488 \\
\hline
\end{tabular}

4. Motif Pemilihan Pangan dan Hubungannya Pemilihan Pangan Terhadap Ketahanan Pangan

Secara umum responden mampu mendapatkan kebutuhan pangan karena ketersediaan pangan yang cukup, akses yang mudah, dan konsumsi yang dapat memenuhi kebutuhan sehari-hari. Namun kondisi cuaca yang menjadi tidak menentu dalam masa peralihan menjadikan sumber pendapatan menurun dari mata pencaharian sebagai nelayan sehingga dapat beresiko mempengaruhi ketahanan pangannya. Dari ketiga indikator ketahanan pangan, rataan indikator Ketersediaan pangan menempati yang paling kuat, kemudian disusul indikator Akses pangan dan Konsumsi pangan. Ketersediaan pangan terlihat dari responden yang memiliki cadangan beras selama seminggu ke depan,
$71 \%$ yang tidak memiliki banyak beras bantuan dari pemerintah, dan tidak pernah tidak memiliki pangan di rumahnya.

Pada indikator Akses pangan, terlihat bahwa responden dapat memperoleh bahan pangan dari dari hasil tangkapan, membeli di warung atau tukang sayur, meskipun masih ditemui responden yang harus mengendarai motor ke pasar untuk berbelanja kebutuhan pangan dengan jarak dari rumah responden ke pasar cukup jauh yaitu lebih dari $7 \mathrm{~km}$. Sementara itu dalam indikator konsumsi pangan, responden pada umumnya makan sebanyak dua kali sehari, yaitu makan siang dan makan malam karena makan pagi dianggap sebagai kudapan. Menu yang disantap responden sewaktu saat makan pagi biasanya berupa lontong dan gado-gado. 
Motif perilaku pemilihan pangan dianggap akan dapat berhubungan dengan capaian ketahanan pangan di rumah tangga responden dari akses pangan, penyediaan pangan, dan konsumsi pangan. Berikut ini adalah hasil uji motif perilaku pemilihan pangan dengan ketahanan pangan.

\section{Motif kesehatan dan ketahanan pangan;}

Hasil uji korelasi Spearman menunjukkan besarnya hubungan antara motif kesehatan dan ketahanan pangan sebesar $r=-0.16$ dengan $p=0.19$. Hasil ini menjelaskan bahwa tidak ada hubungan yang siginifikan antara motif kesehatan dengan ketahanan pangan pada $\alpha<0,05$ (1-tailed).

\section{Motif harga dan ketahanan pangan;}

Terdapat hubungan antara motif harga dan ketahanan pangan dari hasil uji korelasi Spearman sebesar $r=-0.25$ dengan $p=0.09$. Hal ini menggambarkan tidak adanya hubungan yang siginifikan antara motif kesehatan dengan ketahanan pangan pada $\alpha<0,05$ (1-tailed).

\section{Motif pengaruh pihak lain dan ketahanan pangan}

Uji korelasi Spearman menunjukkan hubungan antara motif pengaruh pihak lain dengan ketahanan pangan sebesar $r=0.11$ dengan $p=0.29$. Hasil ini menjelaskan bahwa tidak ada hubungan yang siginifikan antara motif kesehatan dengan ketahanan pangan pada $\alpha<0,05$ (1-tailed).

\section{Motif kebiasaan dan dan ketahanan pangan}

Hasil uji korelasi Spearman menunjukkan besarnya hubungan antara motif kebiasaan dan ketahanan pangan sebesar $r=-0.10$ dengan $p=0.30$. Hal ini berarti tidak adanya hubungan yang siginifikan antara motif kesehatan dengan ketahanan pangan pada $\alpha<0,05$ (1-tailed).
Uji korelasi tiap motif pemilahan pangan dengan ketahanan pangan menunjukkan bahwa tidak cukup kuat untuk menyatakan adanya hubungan yang bermakna antara dua hal tersebut. Oleh karena itu, dalam penelitian ini motif pemenuhan kebutuhan pangan tersebut yang terdiri dari sosial-budaya-ekonomi-serta kesehatan dianggap sebagai suatu struktur motif yang dapat berhubungan dengan ketahanan pangan. Data menunjukkan bahwa perilaku emilih pangan memiliki korelasi moderat dengan ketahanan pangan sebesar $0.33(p<0,05)$. Hal ini berarti bahwa semakin kuatnya tindakan yang ditampilkan dalam pemilihan pangan berdasarkan empat motif akan berhubungan dengan semakin kuatnya ketahanan pangan rumahtangganya. Dalam hal ini motif sosio-budaya-ekonomi-kesehatan berperan dalam membentuk ketahanan pangan responden karena mereka memilih untuk tetap membeli beras dengan jumlah yang cukup, mempertimbangkan harga bahan pangan, memanfaatkan hasil alam seperti kelapa di dekat rumah untuk dijadikan bahan lauk pauk (gulai) seperti budaya khas Minang pada umumnya, dan mengolahnya bahan pangan yang bebas dari MSG dan pengawet. Terlebih lagi ekosistem di kawasan pesisir Desa Taluk dan Desa Marunggi yang tidak hanya berupa pantai dan laut namun juga dipenuhi oleh potensi alam pohon kelapa sehingga turut mendukung ketahanan pangan masyarakat setempat.

Sebanyak $80 \%$ responden yang menampilkan perilaku pemilihan pangan yang kuat berdasarkan empat motif pemilihan pangan memiliki ketahanan pangan (Tabel 9). Responden yang merupakan masyarakat asli Minang beranggapan bahwa keempat motif sebetulnya telah menjadi bagian dari faktor yang mempengaruhi pilihan pangan komunitas pesisir tersebut. Rumahtangga responden yang tahan pangan terlihat memiliki

Tabel 9. Sebaran Responden Berdasarkan Perilaku Memilih Pangan dan Ketahanan Pangan di Desa Marunggi dan Desa Taluk tahun 2018.

Table 9. The Distribution of Respondents Based on Food Choice and Food Security in Marunggi and Taluk VIllage, 2018.

\begin{tabular}{lcrr}
\hline $\begin{array}{c}\text { Perilaku Memilih Pangan Berdasarkan } \\
\text { Empat Motif/ Food Choose Behavior } \\
\text { Based Four Motive }\end{array}$ & \multicolumn{2}{c}{ Ketahanan Pangan/Food Security } & Jumlah/ \\
\cline { 2 - 3 } & $\begin{array}{c}\text { Kurang Tahan Pangan/ } \\
\text { Less Food Security }\end{array}$ & $\begin{array}{c}\text { Tahan Pangan/food } \\
\text { Security Resistant }\end{array}$ & Amount (\%) \\
\hline Lemah/Weak & 11 & 9 & 20 \\
Kuat/Strong & $(55.0 \%)$ & $(45.0 \%)$ & $(100.0 \%)$ \\
Jumlah/Amount & 2 & 8 & 10 \\
& $(20.0 \%)$ & $(80.0 \%)$ & $(100.0 \%)$ \\
\cline { 2 - 3 } & $(43.3 \%)$ & $(56.7 \%)$ & $(100.0 \%)$ \\
\hline
\end{tabular}


persediaan pangan terutama beras, mengakses pangan dekat dengan tempat tinggalnya meski tidak mengkonsumsi sayur dan buah tiap hari. Sementara itu dari responden yang memiliki motif rendah dalam perilaku pemilihan pangannya sebanyak $55 \%$ termasuk Kurang tahan pangan. Hal ini menandakan bahwa pemilihan pangan berdasarkan empat motif, yaitu sosial-ekonomibudaya-kesehatan cukup dapat memprediksi ketahanan pangan pada rumahtangga responden.

Meski begitu, jika berdasarkan modal maka terdapat kecenderungan empat pola dari pengaruh empat motif pilihan pangan responden pada ketahanan pangan. Pertama adalah adanya kecenderungan responden yang memiliki empat motif pemilihan pangan yang kuat dan tahan pangan. Responden yang tahan pangan adalah yang memiliki modal budaya, ekonomi, dan sosial yang masing-masing baik kuat maupun lemah. Hal ini sejalan dengan yang disebutkan oleh Endarwati dan Wahyuni (2014) bahwa modal sosial dapat digunakan untuk mempertahankan ketahanan pangan rumahtangga petani untuk memperoleh pekerjaan usahatani maupun non -usahatani serta Martianto et al., (2017) yang menyatakan bahwa kepercayaan pada rumahtangga miskin dapat menguatkan hubungan sosial untuk lebih meningkatkan pemenuhan akan kebutuhan pangan.

Pola kedua adalah kelompok responden dengan empat motif pangan yang kuat namun cenderung mengalami rawan pangan adalah yang memiliki modal ekonomi dan modal sosial kuat maupun lemah namun dengan modal budaya rendah. Hal ini berarti responden yang memiliki modal ekonomi berupa moda produksi dalam penangkapan ikan serta statusnya sebagai nelayan pemilik, maupun modal sosial berupa kuatnya jaringan, kepercayaan, dan norma dalam komunitas nelayan merupakan sebagai kondisi prasyarat yang tidak mencukupi bagi responden untuk ketahanan pangannya di rumahtangganya. Dengan begitu maka temuan ini dapat berkontribusi pada pentingnya peran dari modal budaya yang berupa pemenuhan pendidikan dasar responden agar dapat menghindari rawan pangan. Pemenuhan pendidikan dasar dianggap akan dapat mendorong responden untuk mengatasi permasalahan dengan kemampuan maupun keterampilan yang diperolehnya selama pendidikan (sekolah) maupun dalam bentuk peningkatan pendapatan akibat pekerjaan di dalam maupun luar nelayan. Modal ini bersama dengan moda penangkapan ikan, status nelayan, dan modal sosial akan dapat meningkatkan akses, penyediaan pangan, dan konsumsi pangan yang cukup di tingkat rumahtangga nelayan.

Yang menarik, di sisi lain ditemui adanya responden yang tindakan memilih pangannya berdasarkan empat motif yang lemah juga ditemui ada yang tahan pangan. Sama seperti dengan responden yang empat motifnya tinggi, ketahanan pangan ini dapat disebabkan oleh dimilikinya modal budaya, ekonomi, dan sosial baik yang lemah maupun kuat. Pola yang terakhir yaitu termasuk rentan dan perlu memperoleh perhatian adalah kelompok responden dengan empat motif yang lemah yang mengalami rawan pangan. Kelompok responden ini cenderung yang memiliki modal budaya, ekonomi, dan sosial yang semuanya termasuk kategori lemah/rendah. Oleh karena itu hal ini menunjukkan bahwa adanya kontribusi dari perilaku memilih pangan yang kurang berdasarkan empat motif (berupa Kebiasaan, Harga, Kesehatan, dan Pengaruh orang lain) dalam memilih pangan serta kurang kuatnya modal ekonomi, budaya, maupun sosial yang dapat menyebabkan munculnya kondisi kurang tahan pangan pada responden. Hasil ini menggambarkan pemilahan pangan responden dalam situasi ekonomi yang mengarah pada rendahnya hasil dari tangkapan (modal ekonomi cenderung rendah) dimana jika responden yang kurang didasari empat motif ini dan modal sosial dan budaya yang juga rendah dapat mengarah pada kurang tahan pangan. Hal ini sejalan dengan Sobal, Bisogni, Devine, \& Jastran (2006) yang menyatakan bahwa proses seleksi dan konsumsi pangan dilakukan dalam suatu konteks yang spesifik, misalnya situasi yang mulai kurangnya hasil tangkapan pada komunitas nelayan karena mulai mendekati musim paceklik dalam penelitian ini. Jumlah tangkapan yang sedikit pada musim paceklik mendorong terjadinya perubahan pendapatan yang semakin berkurang sehingga pada akhirnya dapat menyebabkan kondisi rumahtangga responden menghadapi kesulitan untuk memenuhi kebutuhan pokok. Hasil ini juga akan dapat mendukung kerangka program diversifikasi pangan sebagai kerangka intervensi untuk meningkatkan ketahanan pangan di komunitas dari pemerintah maupun nonpemerintah dengan melengkapi bekerjanya motif pemilihan pangan, yaitu properti sensori, efek mengkonsumsi, dan pertimbangan idealis akan asal pangan, untuk menerima bahan pangan tertentu ke dalam tindakan konsumsi pangan (Rozin, 2006). 


\section{KESIMPULAN DAN REKOMENDASI KEBIJAKAN}

\section{Kesimpulan}

Hasil penelitian menunjukan bahwa ada perbedaan dalam perilaku memilih pangan yang berdasarkan dari empat motif berdasarkan modal budaya dan ekonomi pada rumahtangga nelayan $(\alpha<0,05)$. Hal ini menggambarkan bahwa modal yang dimiliki rumah tangga nelayan, yaitu budaya dan ekonomi, dapat mempengaruhi perolehan kesempatan pemenuhan pangan terlihat didukung data. Modal sosial yang kuat atau lemah nampak tidak membedakan responden secara signifikan meskipun perannya tetap nampak dalam perilaku pemilihan pangan.

Hasil lainnya menunjukkan bahwa terdapat juga hubungan antara perilaku memilih pangan dengan ketahanan pangan sebesar $0,33(\alpha<0,05)$. Dengan demikian maka dapat terlihat bahwa komunitas yang tindakan pemilihan pangannya secara kuat berdasarkan pada empat motif yaitu sosio-ekonomi-budayakesehatan cenderung akan dapat memiliki ketahanan pangan untuk rumahtangganya. Modal ekonomi dan sosial yang kuat belum cukup dapat mengarahkan pada tercapainya kondisi tahan pangan bagi semua rumah tangga nelayan, kecuali bagi nelayan yang mampu mengakumulasi juga modal budayanya. Dengan demikian hasil penelitian ini dapat berkontribusi bagi berbagai pihak agar lebih memperhatikan empat motif ini, yaitu kesehatan, harga, pengaruh sosial, dan kebiasaan sebagai faktor yang mempengaruhi perilaku pemilihan pangan.

\section{Rekomendasi Kebijakan}

Hasil penelitian menunjukkan bahwa empat motif yang mempengaruhi pemilihan pangan yaitu kesehatan, harga, pengaruh sosial, dan kebiasaan. Hasil yang teridentifikasi ini akan dapat digunakan dalam penyusunan indikator ketahanan pangan oleh Badan Ketahahanan Pangan, Kementerian Pertanian, Kementerian Perikanan dan Kelautan maupun pemerintah dan kelembagaan yang berkaitan langsung dengan pemenuhan pangan, gizi, dan kesehatan untuk mengurangi jumlah penduduk yang rawan pangan baik melalui program Desa Mandiri Pangan maupun program pemberdayaan lainnya.
Di dalamnya dapat dilakukan pemetaan kebiasaan pangan penduduk dan faktor modal yang mempengaruhi perilaku pemilihan pangannya dibandingkan dengan hanya memberikan perhatian pada partisipasi pemerintah di tingkat provinsi dan kabupaten dalam melaksanakan monitoring bagi pelaksanaan program. Tidak hanya lembaga ekonomi yang dibangkitkan, namun juga pemetaaan akan motif pemilihan pangan pada anggota rumahtangga di komunitas serta kekuatan modal budaya, ekonomi, dan sosialnya yang dapat berkontribusi pada perilaku pemenuhan ketahanan pangan sejak di tingkat rumah tangga atau desa/komunitas.

Penelitian ini mendorong adanya analisis program ketahanan pangan yang mempertimbangkan aspek sosial berbasis ekosistem, yaitu rumah tangga nelayan pada etnis Minang di kawasan pesisir. Ke depannya, terlihat diperlukannya penelitian dan konfirmasi adanya motif sosio-ekonomi-budaya-kesehatan dalam pemilihan dan konsumsi pangan di komunitas konteks spesifik lainnya, etnis serta ekosistem lainnya, seperti harga turun, paceklik, gagal panen, panen raya, atau musim kemarau karena diprediksi akan berhubungan dengan ketahanan pangan rumahtangganya.

\section{UCAPAN TERIMAKASIH}

Ucapan syukur kepada Allah SWT karena berkat rahmat-Nya, jurnal ini dapat diselesaikan. Kepada pihak-pihak yang terlibat dalam proses dari awal sampai akhir penyusunan jurnal, Pemerintah Kabupaten Pariaman Selatan, Sumatera Barat, masyarakat Kabupaten Pariaman Selatan Khususnya Desa Taluk dan Desa Marunggi yang telah bersedia menjadi responden maupun informan, serta civitas akademika Institut Pertanian Bogor, khususnya di Departemen Sains Komunikasi dan Pengembangan Masyarakat, Fakultas Ekologi Manusia dalam penyelesaian karya ilmiah ini.

\section{PERNYATAAN KONTRIBUSI PENULIS}

Dengan ini kami menyatakan bahwa kontribusi masing-masing penulis terhadap pembuatan karya tulis adalah: Sriwulan Ferindian Falatehan sebagai sebagai kontributor utama, dan Pariyasi sebagai kontributor anggota. Penulis menyatakan bahwa telah melampirkan surat pernyataan kontribusi penulis. 


\section{DAFTAR PUSTAKA}

Agus, M., \& Budiyanto, K. (2012). Tipologi Preferensi Konsumen terhadap Produk Pangan Organik di Kota Malang. Jurnal Humanity, 7, 64-74.

Alpharesy, M. A., Anna, Z., \& Yustiati, A. (2012). Analisis Pendapatan dan Pola Pengeluaran Rumah Tangga Nelayan Buruh di Wilayah Pesisir Kampak Kabupaten Bangka Barat. Jurnal Perikanan Dan Kelautan, 3(1), 1-50.

Anastasi, A., \& Urbina, S. (1997). Psychological Testing. International Edition. Seventh Edition. New Jersey: Prentice-Hall, Inc.

Atmarita. (2018). Asupan gizi yang optimal untuk mencegah stunting. Buletin Jendela Data Dan Informasi Kesehatan, Semester 1.

Badan Ketahanan Pangan. (2018a). Indeks Ketahanan Pangan Indonesia 2018. In Kementerian Pertanian RI.

Badan Ketahanan Pangan. (2018b). Peta Ketahanan dan Kerentanan Pangan Indonesia 2018.

Bourdieu, P. (1984). Distinction : A Social Critique of the Judgement of Taste. Harvard University Press.

Bourdieu, P. (1986). The forms of capital. In J. Richardson (Ed.), Handbook of Theory and Research for the Sociology of Education (pp. 241-258). Greenwood.

Clercq, B. De, Abel, T., Moor, I., Elgar, F. J., Lievens, J., Sioen, I., ... Deforche, Ã. B. (2016). Social inequality in adolescents ' healthy food intake : the interplay between economic, social and cultural capital. The European Journal of Public Health Advance Access, 1-8. https://doi.org/10.1093/ eurpub/ckw236

Damayanti, L. (2007). Faktor yang Mempengaruhi Tingkat Ketahanan Pangan Desa (Studi Kasus di Kabupaten Malang). Agroland, 14(3), 217-222. Retrieved from jurnal.untad.ac.id/jurnal/index. php/AGROLAND/article/.../1779\%0A

Djunaidah, I. S., \& Nurmalia, N. (2018). Peran produktif wanita pesisir dalam menunjang usaha perikanan di Kecamatan Tempuran, Kabupaten Karawang. Jurnal Sosial Ekonomi Kelautan Dan Perikanan, 13 (2)(2), 229-237.

Endarwati, S., \& Wahyuni, E. S. (2014). The Impact of Social Capital on Horticultural Farmer Household Food Security in Ciaruteun llir Village Cibungbulang sub-district Bogor Regency. 10(2), 171-182.

Henryks, J., Brimblecombe, J., \& Bidstrup, G. (2017). Supporting Healthier Food Choices in Remote Indigenous Communities: Developing a Food Choice App. Journal of Food Products Marketing, 23(6), 609-620. https://doi.org/10.1080/1045444 6.2015 .1048028
Kahma, N., Niva, M., Helakorpi, S., \& Jallinoja, P. (2016). Everyday distinction and omnivorous orientation : An analysis of food choice, attitudinal dispositions and social background. Appetite, 96, 443-453. https://doi.org/10.1016/j.appet.2015.09.038

Kamphuis, C. B. M., Jansen, T., Mackenbach, J. P., \& Lenthe, F. J. Van. (2015). Bourdieu's Cultural Capital in Relation to Food Choices : A Systematic Review of Cultural Capital Indicators and an Empirical Proof of Concept. PlosOne. https://doi. org/10.1371/journal.pone.0130695

Markovina, J., Rankin, A., Gibney, M., Fischer, A., Kuznesof, S., Poinhos, R., ... Lj, F. (2015). Validity and Reliability of Food Choice Questionnaire in 9 European Countries. Food Quality and Preference, 45(May), 26-32.

Martianto, D., Alfiasari, \& Dharmawan, A. H. (2017). Modal Sosial dan Ketahanan Pangan Rumah Tangga Miskin di Kecamatan Tanah Sareal dan Kecamatan Bogor Timur, Kota Bogor). Sodality: Jurnal Sosiologi Pedesaan, 3(1), 125-152. https://doi.org/10.22500/sodality.v3i1.5869

Muhartono, R., \& Nurlaili. (2018). Hutang Sebagai Pengikat Hubungan Nelayan dan 'Pengambe ' di Kabupaten Jember, Provinsi Jawa Timur. Jurnal Sosial Ekonomi Kelautan Dan Perikanan, 13 (2) (021), 239-248.

Nurdin, B. V., \& Kartini, Y. (2017). "Belum Makan Kalau Belum Makan Nasi": Perspektif Sosial Budaya dalam Pembangunan Ketahanan Pangan. Jurnal Sosiologi, 19(1), 15-21.

Pechey, R., \& Monsivais, P. (2016). Socioeconomic inequalities in the healthiness of food choices: Exploring the contributions of food expenditures. Preventive Medicine, 88, 203-209. https://doi. org/10.1016/j.ypmed.2016.04.012

Prasodjo, N. W. (2017). Praktik Sosial Pilihan Pangan untuk Anak Balita (Studi pada Komunitas Perdesaan Jawa Barat). IPB University.

Puspadewi, H. R., \& Briawan, D. (2014). Persepsi tentang pangan sehat, alasan pemilihan pangan dan kebiasaan makan sehat pada mahasiswa. Jurnal Gizi Pangan, 9(November), 211-218.

Putnam, R. D. (2000). Bowling Alone. The Collapse and Revival of American Community. New York: Simon \& Schuster.

Rachmi, C. N., Hunter, C. L., Li, M., \& Baur, L. A. (2018). Food choices made by primary carers (mothers/ grandmothers) in West Java, Indonesia. Appetitte, 130(38), 84-92. https://doi.org/10.1016/j. appet.2018.08.005

Rivani, E. (2012). Penentuan Dimensi serta Indikator Ketahanan Pangan di Indonesia: Kaji Ulang Metode Dewan Ketahanan Pangan- World Food Program. Widyariset, 15(1), 151-162. 
Roudsari, A. H., Vedadhir, A., Amiri, P., Kalantari, N., Omidvar, N., Eini-Zinab, H., \& Sadati, S. M. H. (2017). Psycho-Socio-Cultural Determinants of Food Choice: A Qualitative Study on Adults in Social and Cultural Context of Iran. Iranian $J$ Psychiatry, 12(4), 238-247.

Rozin, P. (2006). The Integration of Biological, Social, Cultural and Psychological Influences on Food Choice. In S. Richard \& R. Monique (Eds.), The Psychology of Food Choice. Frontiers in Nutritional Science, No. 3 (Three). Guilford.

Saleha, Q. (2013). Kajian Struktur Sosial dalam Masyarakat Nelayan di Pesisir Kota Balikpapan. Buletin PSP, 21(1), 67-75.

Salim, F. D., \& Darmawaty. (2016). Kajian Ketahanan Pangan Rumah Tangga Nelayan Buruh di Desa Bajo Sangkuang Kabupaten Halmahera Selatan. Jurnal Sosek KP, 11(1), 121-132.

Sobal, J., Bisogni, C. A., Devine, C. M., \& Jastran, M. (2006). A Conceptual Model of The Food Choice Process over the Life Course. In R. Shepherd \& M. Raats (Eds.), The Psychology of Food Choice. Frontiers in Nutritional Science, No. 3 (pp. 75-92). Guilford: CAB International. https:// doi.org/10.1079/9780851990323.0075

Steptoe, A., Pollard, T. M., \& Wardle, J. (1995). Development of a measure of the motives underlying the Selection of food: the Food Choice Questionnaire. Appetite, 25, 267-284.

Syaukat, Y. (2012). Investasi Pertanian dan Ketahanan Pangan Nasional. In A. Fariyanti, A. Rifin, S. Jahroh, \& B. Krishnamurti (Eds.), Pangan Rakyat. Soal Hidup atau Mati 60 Tahun kemudian. Jakarta: Safa Printing.

Vilaro, M. J., Barnett, T. E., Mathews, A., Pomeranz, J., \& Curbow, B. (2016). Income differences in social control of eating behaviors and food choice priorities among southern rural women in the US : A qualitative study. Appetite, 107, 604-612. https://doi.org/10.1016/j.appet.2016.09.003 